\title{
ASUHAN KEBIDANAN KOMPREHENSIF AKSEPTOR AKTIF HORMONAL SUNTIK 1 BULAN PADA Ny "E" DENGAN PENINGKATAN BB DI PUSKESMAS LAMONGAN TAHUN 2015
}

\author{
Ida Susila \\ *Dosen Program Studi D III Kebidanan Universitas Islam Lamongan
}

\begin{abstract}
ABSTRAK
Permasalahan kesehatan reproduksi masih banyak sekali yang harus dikaji, tidak hanya tentang organ reproduksi saja tetapi ada beberapa aspek, salah satunya adalah kontrasepsi. Saat ini tersedia banyak metode atau alat kontrasepsi meliputi IUD, suntik, pil, implant, kontap, kondom. Salah satu kontrasepsi yang populer di Indonesia adalah kontrasepsi suntik. Kontrasepsi suntik yang digunakan adalah Noretisteron Enantat (NETEN), Depo Medroksi Progesteron Acetat (DMPA).

Metode yang digunakan dalam penyusunan Laporan hasil penelitian ini adalah deskripsi observasi yang dilaksanakan dengan pendekatan kohort mulai dari kehamilan sampai kontrasepsi diperoleh dari wawancara, pengkajian data primer, sekunder, pemeriksaan fisik dan dilakukan pendokumentasian SOAP.

Hasil asuhan kebidanan komprehensif akseptor aktif KB hormonal suntik 1 bulan dengan peningkatan $\mathrm{BB}$ terdapat persamaan tinjauan kasus mulai dari pengkajian data subyektif, obyektif, analisa data, dan penatalaksanaan.

Dari hasil asuhan kebidanan diharapkan bidan bisa lebih mengoptimalkan dalam melaksanakan asuhan kebidanan komprehensif Akseptor aktif hormonal suntik 1 bulan dengan peningkatan berat badan dengan manajemen kebidanan SOAP.
\end{abstract}

Kata kunci: Akseptor aktif hormonal, Suntik 1 bulan, Peningkatan BB

\section{PENDAHULUAN}

Permasalahan

kesehatan reproduksi masih banyak sekali yang harus dikaji, tidak hanya tentang organ reproduksi saja tetapi ada beberapa aspek, salah satunya adalah kontrasepsi. Saat ini tersedia banyak metode atau alat kontrasepsi meliputi IUD, suntik, pil, implant, kontap, kondom. Salah satu kontrasepsi yang populer di Indonesia adalah kontrasepsi suntik. Kontrasepsi suntik yang digunakan adalah Noretisteron Enantat (NETEN), Depo Medroksi Progesteron Acetat (DMPA). (Sarwono, 2006).

Namun banyak pengguna kontrasepsi suntik yang berhenti dikarenakan efek sampingnya berupa gangguan pola haid, kenaikan berat 
badan, sakit kepala, dan rasa ketidaknyamanan diperut (Naser etal.2009).

Kontrasepsi suntik memiliki kelebihan dan kekurangan. Kekurangan dari kontrasepsi suntik adalah terganggunya pola haid diantaranya adalah amenorrhea, menoragia dan muncul bercak (spotting), terlambatnya kembali kesuburan setelah penghentian pemakaian, dan peningkatan berat badan (Saifuddin, 2006).

Kontrasepsi suntik 1bulan merupakan jenis suntikan kombinasi yang berisi $25 \mathrm{mg}$ depo medrogsi progesteron asetat dan $5 \mathrm{mg}$ estradiol sipinioat yang diberikan injeksi IM sebulan sekali (Saifuddin,2005).

Secara Nasional pada bulan Januari-Desember 2014 Akseptor Kontrasepsi sebanyak 663.221 peserta yakni 52.321 peserta IUD (7.89\%), peserta MOW (1.49\%), 49.577 peserta implant $(7,47 \%)$, 334.214 peserta suntik $(50,39 \%)$, 176.516 peserta pil $(26.61 \%), 1.691$ peserta MOP $(0,25 \%)$ dan 39.062 peserta kondom $(5,89 \%)$ (BKKBN, 2014).

Menurut tabel provinsi masa kini tahun 2014, jumlah wanita usia subur di propinsi Jawa Timur adalah 5.765 orang dengan pengguna Sterilisasi wanita $(3,5 \%)$, Sterilisasi pria $(0,3 \%)$, Pil $(14,7 \%)$, IUD $(5,0 \%)$, Suntik $(34,7 \%)$ Implant $(3,1 \%)$, Kondom $(1,3 \%)$, Senggama terputus $(1,2 \%)$, lainnya $(0,3 \%)$, tidak memakai KB $(34,7 \%)$ (SDKI, 2012).

Menurut laporan pencapaian Kontrasepsi Dinas Kesehatan Kabupaten Lamongan tahun 2014, jumlah akseptor Kontrasepsi pada tahun 2014 total mencapai 2.304.928 yang meliputi akseptor IUD sebesar 18.064 orang $(7,7 \%)$, akseptor MOW sebesar 6.669 orang $(2,8 \%)$, akseptor MOP sebesar 542 orang $(0,23 \%)$, akseptor kondom sebesar 3.630 orang (1,5\%), akseptor implan sebesar 28.549 orang $(12,2 \%)$, akseptor suntik sebesar 119.516 orang $(51,1 \%)$, dan akseptor pil sebesar $57.050(24,4 \%)$.

Berdasarkan penelitian yang dilakukan di Puskesmas lamongan pada bulan Januari-Desember 2014 yakni dari 7.419 PUS ditemukan orang yang memakai Kontrasepsi Suntik 3 bulan 2.231 orang (30\%) dan Kontrasepsi Suntik 1 bulan 2.100 orang (28\%), Kontrasepsi Pil 1.463 orang (19,7\%), Implan 282 orang $(3,8 \%)$,IUD 678 orang $(9,2 \%)$, kondom 206 orang $(2,7 \%)$ MOW 414 orang $(5,6 \%)$, MOP 45 orang $(0,6 \%)$, Efek samping dari kontrasepsi suntik 1 bulan di antaranya amenorea 40 orang $(0,92 \%)$, spotting 44 orang $(1,01 \%)$, sakit kepala 45 orang $(1,03 \%)$, Menoragia 45 orang $(1,03 \%)$, peningkatan berat badan 46 orang $(1,06 \%)$, dan tidak ada keluhan 1.880 orang $(43,4 \%)$.

Faktor peningkatan berat badan akseptor suntik kemungkinan besar karena kandungan dalam kontrasepsi suntik merangsang pusat pengendali nafsu makan di hipotalamus yang menyebabkan akseptor makan lebih banyak daripada biasanya. Untuk mendapatkan gambaran nyata tentang kejadian peningkatan berat badan yang dialami akseptor kontrasepsi suntik maka perlu dilakukan suatu penelitian untuk mengetahui sejauh mana pengaruh kontrasepsi suntik dengan peningkatan berat badan (Hartanto, 2005). Faktor lain yang berperan penting dalam mempengaruhi berat 
badan diantaranya adalah faktor genetik dan regulasi

Adapun upaya untuk mengatasi masalah peningkatan berat badan ini yakni dengan mengurangi makanan yang mengandung lemak (diet), memperbanyak olahraga seperti senam atau lari-lari kecil dan memberi konseling kepada akseptor bahwa kenaikan atau penurunan berat badan sebanyak 1-2 kg dapat saja terjadi maka perhatikan diet klien bila perubahan berat badan berlebihan, hentikan suntikan dan anjurkan untuk mengganti metode kontrasepsi yang lain seperti Implant, Pil atau IUD (Prawirohardjo, 2011)

Mengingat pentingnya suatu asuhan yang harus diberikan pada klien yang mengalami masalah dengan peningkatan berat badan maka penulis akan mengambil judul " Asuhan Kebidanan Komprehensif Akseptor Aktif Hormonal Suntik 1 Bulan dengan Peningkatan Berat Badan di Puskesmas Lamongan Tahun 2015."

\section{TUJUAN PENELITIAN}

Untuk mengetahui gambaran tentang Pelaksanaan Asuhan Kebidanan Komprehensif Akseptor aktif hormonal Suntik 1 Bulan dengan Peningkatan Berat Badan di Puskesmas Lamongan Tahun 2015.

\section{METODE PENELITIAN}

Dalam pemberian asuhan kebidanan kehidupan pada klien bidan menggunakan metode pendekatan pemecahan masalah dengan difokuskan pada suatu proses sistematis dan analisis. Pemberian asuhan kebidanan tersebut, penulis menggunakan untuk langkah manajemen kebidanan SOAP yakni Subyektif, Obyektif, Analisa Data dan Penatalaksanaan.

\section{HASIL DAN PEMBAHASAN Data subyektif}

Pada data subyektif terdapat persamaan antara tinjauan kasus dan pustaka, untuk tinjaun kasus keluhan utama didapatkan hal yang menunjang pada akseptor hormonal suntik 1 bulan berat badan meningkat, gemuk, nafsu makan yang meningkat, Pada tinjauan pustaka akseptor aktif hormonal suntik 1 bulan dengan peningkatan berat badan memang banyak ditemukan keluhan utama pasien seperti nafsu makan yang meningkat, merasa gemuk dan berat badan naik.

Teori yang mendukung antara tinjauan kasus dan tinjauan pustaka disebabkan karena hormon progesteron yang merangsang pusat pengendalian nafsu makan dihipotalamus yang menyebabkan nafsu makan tidak bisa terkendali (Winknjosastro, 2006).

Dari tinjauan kasus dan tinjauan teori pada akseptor aktif hormonal suntik 1 bulan dengan peningkatan berat badan, memang banyak terdapat persamaan pada keluhan utama adanya nafsu makan yang meningkat karena hormon progesteron yang merangsang pusat pengendalian nafsu makan di hipotalamus.

Dikuatkan oleh teori yang menyebutkan Penyebab peningkatan berat badan pada akseptor suntik 1 bulan kemungkinan disebabkan karena hormon progesteron yang merangsang pusat pengendalian nafsu makan di hipotalamus yang menyebabkan akseptor makan lebih banyak dari pada biasanya (Hartanto, 2004).

\section{Data Obyektif}

Pada data Obyektif terdapat persamaan antara tinjauan kasus dan tinjauan pustaka menurut teori, untuk 
BB dan LILA yang mengalami peningkatan, pada tinjauan kasus diperoleh pemeriksaan antropometri BB sebelum mamakai suntik 1 bulan $58 \mathrm{~kg}$, BB sesudah memakai suntik 1 bulan $72 \mathrm{~kg}$, tinggi badan $155 \mathrm{~cm}$, Pada tinjauan pustaka pada pemeriksaan umum $\mathrm{BB}$ dan LILA terdapat perbedaan antara kasus akseptor aktif hormonal suntik 1 bulan dengan peningkatan BB dengan kasus yang fisiologis yang mengalami peningkatan $\mathrm{BB}$ dan LILA.

Teori yang mendukung persamaan antara tinjauan kasus dan tinjaun pustaka karena kenaikan berat badan adalah efek samping dari pemakaian suntik 1 bulan, akan tetapi tidak selalu kenaikan berat badan tersebut diakibatkan dari pemakaian suntik 1 bulan, menurut teori (Nurahmah, 2007).

Pada kasus suntik 1 bulan dengan peningkatan BB mendapatkan pemeriksaan $\mathrm{BB}$ dan LILA dan hasilnya nanti terjadi peningkatan berat badan setelah memakai kontrasepsi suntik 1 bulan.

Di kuatkan oleh teori yang mengatakan pola konsumsi yang tak terkendali dapat mengakibatkan masalah gizi dan kenaikan berat badan (Overweight) (Waspadji, 2005).

\section{Analisa Data}

Pada analisa data terdapat persamaan antara tinjauan kasus dan tinjauan pustaka, menurut teori (Ayurai, 2009). Masalah aktual pada teori ditemukan masalah yang timbul ditemukan kelebihan berat badan (Overweight), sedangkan pada tinjauan kasus masalah aktual yang timbul akibat peningkatan berat badan ditemukan kelebihan berat badan (Overweight), jadi pada masalah aktual ditemukan persamaan antara tinjauan pustaka dengan tinjauan kasus.

Teori yang mendukung persamaan antara tinjauan kasus dan tinjauan pustaka di hitung menurut rumus versi BMI menurut WHO.menurut teori (Kasdu, 2010).

Pada kasus suntik 1 bulan dengan peningkatan $\mathrm{BB}$, dilakukan pemeriksaan menggunakan rumus BMI dan ditemukan pasien mengalami Overweight dikarenakan nafsu makan yang tak terkendali karena adanya kandungan hormon pada suntik 1 bulan.

Di kuatkan oleh teori rumus berat badan ideal versi BMI menurut WHO yang menyebutkan kategori kelebihan berat badan (overweight) 25-29 ( Hartanto, 2005)

\section{Penatalaksanaan}

Pada penatalaksanaan terdapat persamaan antara tinjauan kasus dan tinjauan pustaka, diperoleh hasil terdapat persamaan antara tinjauan pustaka dan tinjauan kasus. Tinjauan pustaka pada penatalaksanaan memberikan konseling tentang $\mathrm{KB}$ beserta dengan efek sampingnya, mengurangi makanan yang mengandung banyak lemak, melakukan banyak aktifitas, melakukan olahraga, memberikan motivasi dan semangat kepada akseptor tentang perubahan yang dialami, menganjurkan akseptor untuk mengganti alat kontrasepsinya ke kontrasepsi selain hormonal jika berat badan semakin meningkat, tinjauan kasus didapatkan penanganan akseptor hormonal 1 bulan dengan peningkatan berat badan yakni memberikan konseling tentang KB beserta dengan efek sampingnya, mengurangi makanan yang mengandung banyak lemak, melakukan banyak aktifitas, melakukan olahraga, memberikan 
motivasi dan semangat kepada akseptor tentang perubahan yang dialami, menganjurkan akseptor untuk mengganti alat kontrasepsinya ke kontrasepsi selain hormonal jika berat badan semakin meningkat.

Teori yang mendukung antara tinjauan kasus dan tinjauan pustaka sama-sama memberikan HE tentang pola aktifitas, melakukan olahraga, menurut teori.(Saifuddin, 2010).

Pada kasus suntik 1 bulan sama-sama memberikan HE tentang banyak melakukan aktifitas, melakukan olahraga dikarenakan dengan melakukan aktifitas seperti itu bisa menurunkan berat badan pada pasien.

Di perkuat oleh teori yang mengatakan memperhatikan diet klien jika perubahan badan terlalu mencolok,memberikan KIE tentang cara diet rendah kalori yakni diet yang mengandung rendah kalori dengan cukup mengandung nutrient sesuai dengan kebutuhan, dan bila berat badan berlebihan hentikan suntikan dan anjurkan metode kontrasepsi yang lain.

\section{KESIMPULAN DAN SARAN \\ Kesimpulan}

1. Pengkajian Subyektif terdapat persamaan tinjauan kasus untuk keluhan utama pada $\mathrm{kb}$ suntik 1 bulan dengan peningkatan berat badan.

2. Pengkajian Obyektif terdapat persamaan tinjauan kasus untuk pemeriksaan antropometri pada $\mathrm{kb}$ suntik 1 bulan dengan peningkatan berat badan.

3. Analisa Data terdapat persamaan tinjauan kasus untuk masalah aktual kb suntik 1 bulan dengan peningkatan berat badan.

4. Penatalaksanaan terdapat persamaan antara tinjauan kasus untuk dan tianjaun pustaka pada $\mathrm{kb}$ suntik 1 bulan dengan peningkatan berat badan.

\section{Saran}

1. Bagi institusi

Di pergunakan sebagai bahan tambahan kepustakaan yang memerlukan acuan perbandingan pada penanganan khusus dan sebagai referensi Asuhan Kebidanan Komprehensif Akseptor aktif hormonal Suntik 1 Bulan dengan Peningkatan Berat Badan.

2. Bagi Tempat Penelitian

Sebagai bahan pertimbangan bagi lahan praktek untuk lebih mengoptimalkan dalam melaksanakan asuhan kebidanan komprehensif Akseptor aktif hormonal suntik 1 bulan dengan peningkatan berat badan dengan manajemen kebidanan SOAP.

3. Bagi Pasien

Sebagai salah satu sumber pengetahuan bagi masyarakat, khususnya bagi wanita usia subur tentang pentingnya Asuhan kebidanan komprehensif Akseptor aktif hormonal suntik 1 bulan dengan peningkatan berat badan.

\section{DAFTAR PUSTAKA}

Bkkbn, Laporan Pendahuluan SDKI, http://www.bkkbn.go.id/litba ng/pusdu/Hasil\%20Penelitian /SDKI\%202012/Laporan\%20 Pendahuluan\%20SDKI\%202 012.pdf, Diaksespadatanggal 22-05-2013

Bobak, dkk. 2007. Perawatan Maternitas dan Ginekologi. Jakarta : EGC. 
Depkes, RI. 2007. Asuhan Kesehatan Anak dalam Konteks Keluarga. Jakarta : Pusat Pendidikan Tenaga Kesehatan Depkes RI.

Estiwidani, Dwana.2008. Konsep Kebidanan. Jakarta : Fitramaya

Handayani, Sri.2011 Buku Ajar Pelayanan Keluarga Berencana. Yogyakarta : Pustaka Rihama

Hartanto, Hanafi.2010. Keluarga Berencana Dan Kontrasepsi. Jakarta : Pustaka Sinar Harapan

JNPK-KR. 2008. Asuhan Persalinan Normal dan Inisiasi Menyusui Dini. Jakarta: JNPK-KR.

Laboratorium, klinik.2013.Amenorea.http:// prodia.co.id/penyakitdandiagnosa/amenorea.diakse stanggal 15 juni 2013.

Mansjoer, Arif. 2007. Kapita Selekta KedokteranJilid I Edisi ketiga. Jakarta : Media AesculapiusFakultas

Kedokteran Universitas Indonesia.

Manuaba, Ida Bagus Gde. 2007. Pengantar Kuliah Obstetri. Jakarta : EGC.

Manuaba, Ida Bagus Gede. 2008. Ilmu Kebidanan, Penyakit Kandungan dan KB Untuk Pendidikan Bidan. Jakarta : EGC.
Prawirorahardjo, Sarwono. 2007. Ilmu Kebidanan. Jakarta: Bina Pustaka Sarwono Prawirorahardjo.

Prawirohardjo, Sarwono. 2008. Buku Panduan Praktis Pelayanan Kesehatan Maternal dan Neonatal. Jakarta. Yayasan Bina Pustaka Sarwono Prawirahardjo.

Senoputra, Andrian. Penyebab dan Penanganan Amenorea.http://beritacyber. Diakses tanggal 15 juni 2013.

Syaifudin, Abdul Bari. Afandi, Biran. Baharudin, Moh. SoekirSoekaemi.2010. Buku Panduan Praktis Pelayanan Kontrasepsi.Jakarta : Yayasan Bina Pustaka Sarwono Prawirohardjo.

Suherni, dkk. 2009. Perawatan Masa Nifas. Yogyakarta: Fitramaya.

Winkjosastro, Hanifa. 2007. Ilmu Kebidanan. Jakarta : EGC.

Winkjosastro, Hanifa. 2008. Ilmu Kebidanan. Jakarta : EGC. 
